\title{
Effort Increasing Learning Result Of Communication Operations Calculating Methods Using Napier Bone Students Class Students In Basic Schools 12 Tebat Karai
}

Lelawarna

SDN 12 Tebat Karai

lelawarna32@gmail.com

\begin{abstract}
This study aims to determine whether the use of Napier Bone Exam can improve mathematics learning outcomes in multiplication counting operations. The method in this study is a classroom action research with a collaborative form involving researchers who are also as principals, and peers of teachers.This research was conducted in class V at State SDN 12 Tebat Karai District in Kepahiang in the school year 2015/2016 with the number of students 20 people. The focus of this research is the result of mathematics learning on multiplication counting and the effectiveness of napier bone wear. Action Research This class uses two cycles. Each cycle consists of four steps: planning, action, observation and reflection. The results showed an increase, this is evidenced by the results obtained in cycle I and cycle II with SK / KD as well as different indicators in the category of very good. By looking at the results of this study can be concluded that this research is able to answer the purpose of research that the use of napier bone skeleton can improve the results of mathematics learning on the multiplication counts class $V$ students in SDN 12 TebatKaraiKepahiang Regency 2015/2016. Other data relating to research and student work as attached. Finally, researchers suggest to all teachers to be creative in presenting lessons, especially in using props and media that are interesting and varied so that it can bring students in a fun learning process and thorough completion of student learning outcomes can be achieved.
\end{abstract}

Keywords: Results of mathematics learning, Napier Bone Exhibition

\section{Pendahuluan}

Matematika merupakan salah satu mata pelajaran pokok, mata pelajaran wajib yang ada di setiap jenjang pendidikan dasar dan menengah. Matematika juga menjadi salah satu dari tiga mata pelajaran yang mulai tahun ajaran 2015/2016 di masukkan dalam UASBN. Sampai sekarang masih ada siswa yang kurang berminat terhadap Matematika dan prestasi belajar Matematikapun belum menunjukkan hasil yang optimal.

Siswa sekolah dasar mulai mengenal operasi hitung perkalian ketika berada di kelas II. Seharusnya mereka sudah mengetahui konsep dasarnya ketika berada di kelas rendah dan sudah bisa mengaplikasikan konsep tersebut ke dalam materi yang lainnya ketika berada di kelas yang lebih tinggi yaitu kelas IV,V dan VI. Kenyataannya siswa kelas V yang termasuk kelas tinggi, banyak yang belum hafal 
perkalian dasar. Untuk mengerjakan perkalian dua angka atau lebih mereka masih kesulitan. Kesulitan itu terlihat pada operasi hitung perkalian ketika tes akhir pembelajaran matematika, untuk materi operasi hitung perkalian di kelas V SD Negeri 12 Tebat Karai Kabupaten Kepahiang Propinsi Bengkulu menunjukkan hasil yang kurang memuaskan. Oleh sebab itu Kriteria Ketuntasan Minimal (KKM) untuk Standar Kompetensi 1 dan Kompetensi Dasar 3 belum tercapai karena nilai sebagian siswa masih di bawah KKM yaitu di bawah 70 .

Masalah yang juga sering muncul adalah siswa dalam kondisi terpaksa harus menelan dan menghafal secara mekanis apa-apa yang telah di sampaikan oleh guru, sehingga menjadikan para siswa tidak memiliki keberanian untuk mengemukakan pendapat, tak kreatif dan mandiri, apalagi untuk berfikir inovatif. Selain itu, pendekatan pembelajaran matematika masih menggunakan pendekatan tradisional, yaitu duduk dengar catat dan hafal. Pembelajaran jadi membosankan, tidak menarik dan hasilnya tidak memuaskan. Waktu untuk mengerjakan soalpun terasa lebih lama, sehingga tidak semua soal dapat terjawab dengan cepat dan benar.

Mata Pelajaran Matematika pada diberikan kepada siswa kelas V SD pada semester satu (I) untuk membekali siswa berpikir logis, analitis, sistematis, kritis, dan kreatif serta mampu bekerja sama. Kompetensi tersebut diperlukan agar siswa dapat memiliki kemampuan memperoleh, mengelola, dan memanfaatkan informasi untuk bertahan hidup pada keadaan yang selalu berubah, tidak pasti, dan kompetitif. Untuk menguasai mata pelajaran matematika secara baik, diperlukan pemahaman konsep dan prosedur (algoritma) secara baik pula.

Pemahaman konsep matematika tidak lahir dengan sendirinya, tetapi diproses melalui tatanan kehidupan pembelajaran. Tatanan kehidupan pembelajaran di sekolah secara formal yang paling dominan adalah pembelajaran. Berarti, praktik pembelajaran di sekolah idealnya dapat meningkatkan pemahaman konsep siswa. Akan tetapi, ada sinyalemen bahwa sebagian praktik pembelajaran model pada pelajaran matematika belum secara serius dikembangkan berdasarkan prinsipprinsip yang sahih untuk memberikan peluang siswa belajar cerdas, kritis, kreatif, dan memecahkan masalah. Sebagian besar praktik pengajaran di sekolah masih menggunakan cara-cara lama yang dikembangkan dengan menggunakan intuisi, atau berdasarkan pengalaman sejawat.

Mata Pelajaran Matematika tentang perkalian bilangan dilaksanakan semester gasal tahun 2015/2016, sehingga belum tahu kesenjangannya. Namun kesenjangan tersebut dapat diasumsikan relevan dengan kesenjangan yang ada pada mata pelajaran matematika yang diupayakan guru kelas pada SD Negeri 12 Tebat Karai Kabupaten Kepahiang Propinsi Bengkulu. Asumsi ini peneliti ambil, karena peneliti sekaligus yang berkolaborasi dengan guru kelas,guru kelas tersebut sama, materi ajar, sarana-prasarana dan lingkungan sekolah serta karakteristik siswanya tidak jauh berbeda.

Mata Pelajaran matematika yang diupayakan guru kelas atau guru matematika belum menunjukkan sebagai suatu proses peningkatan pemahaman konsep siswa. Proses pembelajaran masih sebatas sebagai proses transfer of knowledge, bersifat verbalistik dan cenderung bertumpu pada kepentingan guru dari bukan pada kebutuhan siswa yang lazim disebut teacher centered. Hal ini didukung hasil pengamatan peneliti pada semester gasal tahun sebelumnya, yaitu adanya kecenderungan guru dalam memilih dan menggunakan metode mengajar bersifat spekulatif, yang berakibat kegiatan pengajaran kurang menarik, tidak menantang, dan sulit mencapai target prestasi yang ditentukan (KKM). Berdasarkan hal tersebut, peneliti menemukan kesenjangan-kesenjangan kemampuan pemahaman konsep siswa. 


\section{Metode}

Penelitian ini dilaksanakan di kelas V SD Negeri 12 Tebat Karai Kabupaten Kepahiang. Dipilihnya kelas tersebut sebagai objek penelitian karena Peneliti adalah GuruKelas V yang setiap waktu dapat mengamati tingkah laku siswa dan menerima langsung hasil laporan nilai siswa kelas V SD Negeri 12 Tebat Karai Kabupaten Kepahiang, sehingga memudahkan proses penelitian.Penelitian ini dilaksanakan pada bulan Oktober 2015 sampai dengan Deseember 2015 dan pada akhir bulan Desember 2015penelitian ini selesai.Subyek penelitian adalah siswa kelas V SD Negeri 12 Tebat Karai Kabupaten Kepahiang dengan jumlah siswa 20 orang karena dipandang bahwa kelas $\mathrm{V}$ masih mengalami kesulitan dalam operasi hitung perkalian.

Sumber data berasal dari studi pustaka terhadap buku - buku nilai siswa kelas V termasuk nilai ulangan harian dan nilai pada raport kelas sebelumnya. Sedangkan data pendukung berasal dari teman sejawat yang ikut menjadi pengamat.Dalam penelitian ini tidak menggunakan uji statistik. Data hasil observasi dianalisis dengan analisis diskriptif komparatif yaitu membandingkan nilai pre-tes dan pos-tes siklusI dan siklus II serta antar siklus maupun dengan indikator kinerja.

\section{Hasil}

Penelitian ini dilaksanakan di SD Negeri 12 Tebat Karai Kabupaten Kepahiang. Berdasarkan sejarah berdirinya, SD Negeri 12 Tebat Karai Kabupaten Kepahiang berdiri sejak tahun 1982, sekolah merupakan kebutuhan masyarakat yang sangat vital. secara geografis bahwa keadaan perkampungan terpencar-pencar sehingga dibutuhkan berdirinya sekolah untuk menampung peserta didik.

Selaras dengan perkembangan SD Negeri 12 Tebat Karai Kabupaten Kepahiang mendapat simpatik dari masyarakat ternyata baik jumlah murid maupun prestasi dari tahun ke tahun sejak mulai operasional tahun ajaran 1982/1983 semakin meningkat. Hal ini tidak lepas dari peran serta masyarakat yang dikelola orang tua murid melalui BP3 yang sekarang disebut Komite Sekolah, tokoh masyarakat dan perangkat desa, peran aktif masyarakat dan kerjasama antara Komite sekolah dan tokoh masyarakat ternyata tidak sia-sia, dengan dibuktikannya adanya peningkatan kualitas hasil pendidikan.Keberadaan tenaga pendidik mayoritas berasal dari daerah setempat yaitu dari wilayah Kabupaten Kepahiang dan sekitarnya, akan tetapi keberadaan yang berasal dari luar wilayah tidak mempengaruhi tugasnya.

Keadaan personil guru dan pegawai di SD Negeri 12 Tebat Karai Kabupaten Kepahiang terdiri dari seorang kepala sekolah, 6 orang guru kelas dan guru mapel 3 orang serta dibantu oleh 3 tenaga honorer baik sebagai tenaga administrasi, perpustakaan dan penjaga sekolah.

Berdasarkan tes uji kompetensi matematika pada pokok bahasan operasi hitung perkalian, ternyata hasilnya kurang memuaskan, padahal guru sudah berusaha semaksimal mungkin menanamkan konsep perkalian dengan teknik menyimpan. Begitu juga dengan hasil belajar siswa ketika diberi pretes sebelum diadakan proses pembelajaran diperoleh hasil rata - rata 6.32. Hal ini membuktikan bahwa selama ini konsep yang diterima siswa tentang perkalian bersusun belum tercapai. Oleh karena itu, peneliti meminta bantuan teman sejawat untuk bersama - sama mengidentifikasi kekurangan dari pembelajaran matematika yang telah dilaksanakan. Siswa kurang menguasai konsep yang di berikan guru meskipun sudah dijelaskan dan diberi contoh berkali - kali. Sehingga guru harus berusaha menarik perhatian siswa melalui perbaikan pembelajaran. Salah satu upaya peneliti untuk memperbaiki pembelajaran dengan menggunakan media atau alat peraga 
yang berupa tulang napier supaya konsep dari perkalian dengan teknik menyimpan dapat dikuasai siswa dengan baik sehingga diharapkan hasil belajar matematika siswa meningkat.

\section{Siklus I}

Perbaikan pembelajaran pada siklus I dilakukan untuk pokok bahasan perkalian dua angka dengan satu angka dan sudah menggunakan peraga tulang napier. Perbaikan pembelajaran pada siklus I merupakan perbaikan pembelajaran dari hasil pembelajaran yang dilaksanakan sebelumnya. Dalam rencana pembelajaran yang telah dirumuskan yaitu melakukan operasi hitung perkalian dengan indikator (1) Melakukan operasi perkalian dua angka dengan satu angka (2) Melakukan operasi perkalian tiga angka dengan satu angka.

Sebelum dilaksanakan pembelajaran dengan menggunakan alat peraga, dilakukan pre-tes untuk mengetahui seberapa jauh hasil belajar yang dimiliki siswa kelas V SD Negeri 12 Tebat Karai Kabupaten Kepahiang. Ternyata dalam mengerjakan tes, baik tes dalam proses maupun tes akhir hasilnya kurang memuaskan dan waktu yang digunakan terlalu lama. Adapun dari hasil pre-tes diperoleh nilai rata-rata 6.32 dan sebagian siswa nilainya masih di bawah KKM.

\section{Pelaksanaan Tindakan}

Setelah mengadakan pretes, guru melaksanakan pembelajaran sesuai dengan yang sudah direncanakan dalam Rencana Pelaksanaan Pembelajaran indikator 1, melakukan operasi perkalian dua angka dengan satu angka. Urutan kegiatan yang dilaksanakan mulai dari kegiatan awal, kegiatan inti dan kegiatan akhir. Dalam kegiatan awal guru membuat apersepsi yang berupa nyanyian untuk memberikan semangat dan kekompakan untuk mengikuti pelajaran. Siswa dibentuk dalam beberapa kelompoak. Kemudian secara klasikal guru memberikan contoh penggunaan peraga tulang napier untuk menyelesaikan soal. Kegiatan akhir dilaksanakan dengan memberikan postes dan memberikan tugas rumah untuk membuat peraga tulang napier sederhana. Nilai hasil pretes dan postes dapat dilihat dari tabel 1. Dari data tersebut dapat dilihat adanya kenaikan yang cukup signifikan yaitu rata - rata 6.32 menjadi 7.32 .

\section{Hasil Pengamatan}

Pengamatan atau observasi dilaksanakan secara intensif dan berkelanjutan. Data yang dikumpulkan meliputi data :

1) Perilaku siswa selama proses pembelajaran sesuai dengan format pengamatan perilaku siswa.

2) Penilaian hasil pelaksanaan pembelajaran.

3) Aktifitas guru selama pembelajaran.

Guru berkolaborasi dengan teman sejawat untuk mengamati pembelajaran yang sedang dilaksanakan. Hasil pengamatan observer tentang siswa antara lain adanya beberapa siswa mulai aktif bertanya tentang alat peraga yang diperlihatkan, siswa mulai mencoba menggunakan alat peraga secara bergantian dan sangat antusias untuk menyelesaikan soal dengan peraga tulang napier. Namun dalam siklus I ini , guru belum dapat memfasilitasi siswa secara optimal, terbukti nampak masih adanya siswa yang pasif ketika kegiatan pembelajaran berlangsung.

Dari lembar pengamatan untuk guru dapat disimpulkan bahwa guru sudah melaksanakan pembelajran dengan baik. Namun guru masihmemberikan bimbingan secara kelompok dan belum melakukan bimbingan secara individual pada siswa 
yang secara individu mengalami kesulitan dalam menggunakan peraga dalam pembelajaran.

Refleksi

Refleksi dilaksanakan untuk mengulas pembelajaran yang sudah dilaksanakan. Pada kegiatan ini ditemukan beberapa kekurangan dalam pembelajaran antara lain:

1) Penjelasan guru tentang penggunaan alat peraga terlalu tergesa-gesa sehingga siswa merasa belum maksimal dalam menerimanya (karena dibatasi waktu).

2) Alat Peraga yang digunakan hanya 1 sehingga siswa kesulitan dalam menggunakannya karena ada beberapa kelompok.

3) Siswa kesulitan mengunakan alat peraga untuk angka yang jaraknya berjauhan.

Berdasarkan hasil refleksi di atas dipandang perlu adanya rencana tindakan sebagai berikut:

1) Masing - masing kelompok harus mempunyai alat peraga yang dibuat secara sederhana.

2) Alat peraga sebaiknya dipotong tiap angka agar dapat digunakan untuk angka yang berjauhan.

3) Adanya penambahan soal untuk dipecahkan dalam Lembar Kerja Siswa.

\section{Siklus II}

Pelaksanaan pembelajaran pada siklus II, merupakan perbaikan pembelajaran siklus I dengan indikator yang berbeda. Pada dasarnya siklus II memiliki prinsip kerja sama dengan pelaksanaan tindakan siklus pertama. Hanya pada siklus kedua ini pada tahap persiapan dilakukan dengan mendasarkan pada hasil observasi, refleksi pelaksanaan tindakan siklus I.

Langkah -langkah pembelajarannya sama namun indikator yang diambil berbeda yaitu (1) Melakukan operasi perkalian dua angka dengan dua angka (2) Melakukan operasi perkalian tiga angka dengan dua angka. Peneliti berusaha memperbaiki semaksimal mungkin untuk memperbaiki pembelajaran dengan menanamkan konsep perkalian bersusun dengan baik agar hasil belajar matematika meningkat.

Pelaksanaan pembelajaran pada siklus II ini guru sebagai peneliti mengadakan diskusi dengan teman sejawat tentang kekurangan - kekurangan yang ada pada siklus I dan segera membuat perbaikannya. Pada siklus II ini setiap siswa dalam kelompok sudah menggunakan peraga tulang napier yang sudah dibuat di rumah sebagai pekerjaan rumah.

\section{Siklus $I$}

Kegiatan penelitian tindakan kelas pada siklus I (pertama) dikatakan telah terlaksana dengan lancar dan berhasil dengan baik, apabila para siswa yang menjadi subyek penelitian telah meningkat prestasi belajarnya. Indikasi keberhasilan ditunjukkan melalui hasil pretes dan postes yang meningkat dari nilai rata-rata 60.32 menjadi 70.32 Dari 20 siswa kelas V ternyata yang menguasai perkalian bersusun dua angka dengan satu angka dan tiga angka dengan satu angka hanya 15 anak. Mereka dapat menyelesaikan dengan waktu yang telah ditentukan dan berhasil memperoleh nilai diatas 60. Sedangkan sisanya yaitu sebanyak 10 siswa belum berhasil mencapai nilai batas tuntas minimal yang ditentukan. Setelah dilakukan tindakan yaitu penggunaan peraga dalam pembelajaran ternyata hasilnya meningkat. Sebanyak 15 siswa berhasil memperoleh nilai di atas standar minimal yang ditentukan dan hanya 5 siswa yang belum berhasil. Tingkat keaktifan dalam pembelajaranpun meningkat. Mereka menjadi lebih semangat dan sangat antusias untuk mengikuti pelajaran. 


\section{Siklus II}

Kekurangan yang ada pada siklus I diperbaiki dalam siklus II. Dalam hal ini peneliti sebagai guru bekerja sama dengan teman sejawat melakukan perbaikan dalam pembelajaran. Guru sebagai peneliti mencoba untuk menggunakan alat peraga tulang napier tersebut pada indikator yang berbeda. Perkalian dua angka dengan dua angka dan tiga angka dengan dua angka menjadi indikator yang akan diuji cobakan pada Siklus II ini. Keberhasilan pengggunaan peraga pada siklus I menjadikan anak - anak semakin penasaran. Apakah penggunaan peraga ini juga dapat meningkatkan hasil belajar mereka pada indikator yang berbeda. Sebelum dilaksanakan pembelajaran guru memberikan pretes pada siswa. Hasil pretes untuk siklus yang kedua ini ternyata tidak jauh berbeda dengan siklus I. Terdapat 5 siswa yang belum menguasai perkalian bersusun.

Setelah data kuantitatif dan data kualitatif hasil penelitian tindakan kelas pada Siklus I dan Siklus II di analisis kemudian digunakan untuk menguji hipotesis. Selanjutnya secara lengkap dilaporkan hasilnya pada bagian berikut.

\section{Pembahasan}

Operasi hitung perkalian dengan menggunakan Batang Napier pada dasarnya adalah menerjemahkan persoalan perkalian menjadi persoalan penjumlahan. Menurut Iruliana (2010) kelebihan dari Batang Napier ini gambar/angkanya dapat dengan mudah dipindahkan sehingga siswa lebih antusias untuk aktif secara fisik unytuk memindahkan objek angka yang dikalikan. Pola pengajarannyapun dapat memudahkan siswa dalam mengalikan angka yang satu dengan angka yang lain, karena nagka-angkanya tersusun dalam kotak persegi yang dapat dilihat secara langsung.

Data temuan hasil penelitian diperoleh dari hasil perbaikan pembelajaran yangtelah dilaksanakan pada pembelajaran siklus I dan siklus II. Hasil analisis pengamatan tes pelaksanaan perbaikan pembelajaran pada siklus I yang telah dilakukan penelitian oleh peneliti dan teman sejawat diperoleh hasil sebagai berkut :

Dari hasil yang di dapat diketahui bahwa nilai rata-rata hasil belajar siswa pada indikator perkalian dua angka dengan satu angka dan dua angka dengan dua angka meningkat dari 20 siswa menjadi 2 Siswa yang berada pada interval baik sekali juga meningkat dari 15 menjadi 18 dengan prosentase $65 \%$ menjadi $75 \%$. Kenaikan yang cukup signifikan juga terjadi pada kategori sangat kurang, yaitu meningkat dari 75 $\%$ menjadi $35 \%$. Hanya 5 siswa yang belum mencapai kriteria ketuntasan minimal. Secara keseluruhan hasil yang diperoleh adalah meningkat. Hasil selengkapnya dapat di lihat pada tabel di bawah ini.

Tabel 1. Perbandingan Hasil Pre-tes dan Pos-tes pada Siklus I

\begin{tabular}{|c|c|c|c|c|c|}
\hline \multirow[t]{2}{*}{ No } & \multirow[t]{2}{*}{ Interval Nilai } & \multicolumn{2}{|c|}{ Frekuensi } & \multicolumn{2}{|c|}{ Prosentase (\%) } \\
\hline & & Pre-tes & Pos-tes & Pre-tes & Pos-tes \\
\hline 1 & 81- 100 ( Baik Sekali) & 0 & 2 & $0 \%$ & $10 \%$ \\
\hline 2 & $61-80$ ( Baik ) & 6 & 8 & $30 \%$ & $40 \%$ \\
\hline 3 & $41-60$ (Cukup) & 2 & 10 & $10 \%$ & $50 \%$ \\
\hline 4 & $21-40$ (Kurang) & 2 & 0 & $10 \%$ & $0 \%$ \\
\hline 5 & $0-20$ (Sangat kurang) & 10 & 0 & $50 \%$ & $0 \%$ \\
\hline & Jumlah & 20 & 20 & $100 \%$ & $100 \%$ \\
\hline
\end{tabular}

Pada Siklus kedua, indikator yang digunakan adalah perkalian tiga angka dengan satu angka dan tiga angka dengan satu angka. Penggunaan alat peraga Tulang 
Napier pada siklus II ini menjadi lebih menarik dan siswa merasa sudah tidak asing lagi. Dalam siklus II, siswa lebih diaktifkan dan dilibatkan. Kekurangan kekurangan yang ada di siklus I disempurnakan dan hasilnya mengalami kenaikan yang signifikan. Nilai rata-rata pun meningkat dari 51 menjadi 81.72 Peningkatan hasil belajar pada siklus II, dapat dilihat di bawah ini :

Dari hasil di atas dapat diketahui bahwa hasil belajar siswa pada pokok bahasan perkalian, indikator perkalian tiga angka dengan satu angka dan tiga angka dengan dua angka mengalami kenaikan yang cukup besar. Hal ini berarti hasil belajar siswa meningkat hampir $100 \%$ karena dari 20 siswa hanya ada 2 siswa yang belum tuntas. Seperti halnya Siklus I di dalam suklus II inipun nilai siswa dikelompokkan menjadi lima interval yaitu kategori sangat kurang, kurang, cukup, baik dan sangat baik.

\section{Tabel 2. Perbandingan Hasil Pre-tes dan Pos-tes pada Siklus II}

\begin{tabular}{|c|l|c|c|c|c|}
\hline \multirow{2}{*}{ No } & \multicolumn{1}{|c|}{ Interval Nilai } & \multicolumn{2}{|c|}{ Frekuensi } & \multicolumn{2}{c|}{ Prosentase (\%) } \\
\cline { 3 - 6 } & & Pre-tes & Pos-tes & Pre-tes & Pos-tes \\
\hline 1 & $81-100$ (Baik Sekali) & 1 & 13 & $0.5 \%$ & $65 \%$ \\
2 & $61-80$ ( Baik) & 17 & 7 & $85 \%$ & $35 \%$ \\
3 & $41-60$ ( Cukup ) & 2 & 0 & $10 \%$ & $0 \%$ \\
4 & $21-40$ ( Kurang) & 0 & 0 & $0 \%$ & $0 \%$ \\
5 & $0-20$ (Sangat kurang) & 0 & 0 & $0 \%$ & $0 \%$ \\
\hline \multicolumn{2}{|c|}{ Jumlah } & $\mathbf{2 0}$ & $\mathbf{2 0}$ & $\mathbf{1 0 0 \%}$ & $\mathbf{1 0 0 \%}$ \\
\hline
\end{tabular}

Peningkatan rata-rata nilai prestasi belajar dan tingkat ketuntasan belajar siswa secara klasikal dapat di jelaskan sebagai berikut:

1. Pada Siklus I nilai tertinggi yang dicapai siswa adalah 80 dan nilai terendah 40 dengan rata-rata 30. Sedangkan siswa yang tidak mencapai ketuntasan ada 13 siswa.

2. Pada Siklus II nilai tertinggi yang dicapai siswa 95 dan nilai terendah 65 dengan rata-rata 74.65 Sedangkan siswa yang tidak mencapai ketuntasan hanya 2 siswa.

Hasil pengamatan sikap terdapat peningkatan yang nampak jelas perkembangannya. Siswa menjadi lebih aktif bekerja dengan kelompoknya, siswa merasa senang dengan alat peraga yang digunakan sehingga siswa tampak tidak bosan mengikuti pembelajaran yang pada akhirnya hasil belajar matematika pada operasi perkalian menjadi meningkat.

\section{Simpulan}

Berdasarkan data hasil penelitian pada pembelajaran Siklus I dan Siklus II yang telah dilaksanakan di kelas V SD Negeri 12 Tebat Karai Kabupaten Kepahiang, maka dapat ditarik simpulan sebagai berikut :

1. Peraga dan media Tulang Napier yang digunakan dalam menanamkan konsep operasi hitung perkalian bersusun dengan teknik menyimpan dapat menjadikan proses pembelajaran menjadi aktif, kreatif,efektif dan mendorong terciptanya suasana pembelajaran yang menyenangkan pada pelajaran matematika.

2. Pembelajaran matematika pada operasi hitung perkalian bersusun dengan peraga Tulang Napier dapat meningkatkan penguasaan materi pelajaran pada siswa, terbukti dengan hasil belajar matematika meningkat secara signifikan.

\section{Saran}

Setelah diketahui bahwa pembelajaran dengan menggunakan peraga Tulang Napier dapat meningkatka hasil belajar siswa, maka saran yang dapat disampaikan peneliti adalah sebagai berkut : 
1. Siswa seharusnya belajar matematika tidak hanya dengan menerima atau menghafalkan materi, tetapi mempelajarinya sebagai proses yang harus dipahami.

2. Penggunaan metode yang bervariasi dan peraga yang yang dapat dimanipulatif siswa dapat meningkatkan kemampuan siswa dalam mencapai tujuan yang telah ditetapkan oleh guru.

3. Kreatifitas guru dalam menyajikan pembelajaran terutama dalam menggunakan alat peraga dapat membina dan mendorong siswa untuk berpartisipasi aktif dalam proses pembelajaran.

4. Kepada lembaga, agar hasil penelitian tindakan kelas ini dapat digunakan sebagaii bahan masukan bahwa penggunaan peraga dalam pembelajaran dapat digunakan untuk meningkatkan sistem pembelajaran yang lebih efektif, sehingga dapat meningkatkan hasil belajar siswa.

\section{Referensi}

Departemen Pendidikan Nasional. 2001. Standar Kompetensi Dasar Guru. Jakarta: Departemen Pendidkan Nasional.

Departemen Penddikan Nasional. 2003. Undang-undang No. 20 Tahun 2003 tentang Sistem Pendidkan Nasional. Jakarta : Departemen Pendidkan Nasional

Departemen Penddikan Nasional. 2006. Kurikulum Tingkat Satuan Pendidikan. Jakarta : Departemen Pendidkan Nasional

Dimyati dan Mudjiono. 2002. Belajar dan Pembelajaran. Jakarta: Rineka Cipta.

Handoko, T. (2006). Terampil Matematika V. Jakarta:Yudistira

Iruliana. (2010). Batang Napier. Blogspot.com

Kurikulum SD Negeri 12 Tebt Karai (2015)

Margono. (1998). Metodologi penelitian Pendidikan. Semarang: Rineka cipta.

Sagala. S (2005) Konsep dan Makna Pembelajaran Bandung: CV Alfabeta

Mulyani, S. (2001). Strategi Belajar Mengajar. Depdikbud Dirjen Dikti. Proyek Pendidikan Guru Sekolah Dasar.Jakarta.

Sudjana, N. dan Suwariyah, W. (1996). Model-Model Mengajar CBSA. Bandung: Sinar Baru.

Ngalim, P. 1999. Psikologi Pendidikan. Bandung: Remaja Rosda Karya.

Slameto 2003. Proses Belajar Mengajar Dalam Sistem Kredit. Jakarta. Bina Aksara.

Arikunto, S. 1998. Prosedur Penelitian Suatu Pendekatan Praktek. Jakarta: Rineka Cipta.

Suherman, E, dan Putra, U. S W.(1999). Strategi Belajar Mengajar Matematika. Jakarta: Depdikbud. 